\title{
MAKALAH \\ MODERNISASI DAN WESTERNISASI DI INDONESIA
}

Diajukan untuk memenuhi tugas mata kuliah Sejarah Eropa (872010001473)

Dosen Pengampu:

Dr. Mohamad Zaenal Arifin Anis, M.Hum.

Mansyur, S.Pd., M.Hum.

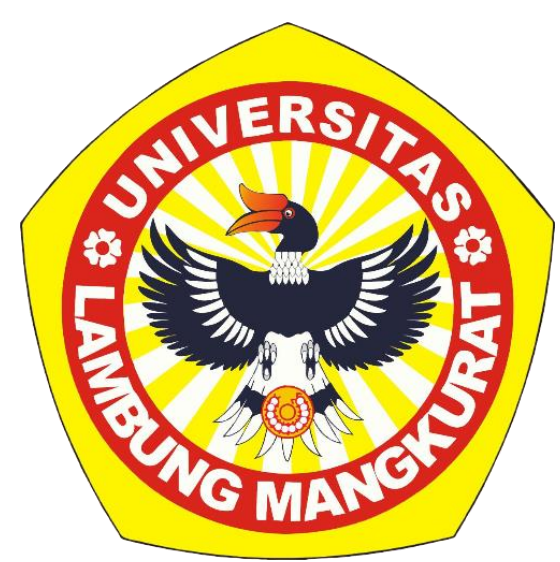

Disusun oleh:

Kelompok 2 Kelas A2

Muhammad Raihan Budiman

2010111110007

Ahmad Syarwani

2010111310009

Galuh Nur Syifa

2010111320002

PROGRAM STUDI PENDIDIKAN SEJARAH

JURUSAN PENDIDIKAN ILMU PENGETAHUAN SOSIAL

FAKULTAS KEGURUAN DAN ILMU PENDIDIKAN

UNIVERSITAS LAMBUNG MANGKURAT

BANJARMASIN

2021 


\section{KATA PENGANTAR}

Segala puji dan syukur hanya milik Allah SWT, shalawat dan salam selalu tercurahkan kepada Baginda Kita Nabi besar Muhammad SAW. Berkat limpahan rahmat dan karunia-Nya, penulis mampu menyelesaikan makalah ini yang berjudul Modernisasi dan Westernisasi di Indonesia.

Makalah ini dapat terselesaikan tidak lepas karena bantuan dan dukungan dari berbagai pihak yang tulus dan sabar memberikan sumbangan baik berupa materi pembahasan, ide, dan juga bantuan lainnya yang tidak dapat dijelaskan satu persatu.

Makalah ini disusun agar pembaca dapat memperluas wawasan mengenai modernisasi dan westernisasi di Indonesia dan dampak bagi Indonesia yang penulis sajikan dari berbagai sumber informasi dan referensi lainnya.

Penulis sadar bahwa makalah ini masih banyak kekurangan dan jauh dari sempurna. Untuk itu, kepada dosen pengampu, penulis meminta masukannya demi perbaikan pembuatan makalah penulis di masa yang akan datang dan mengharapkan kritik dan saran dari para pembaca.

Penulis 


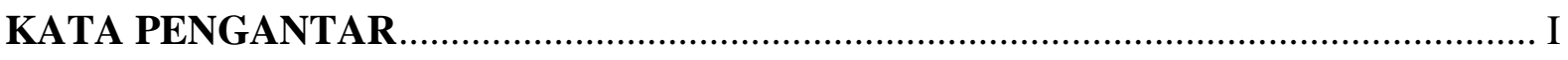

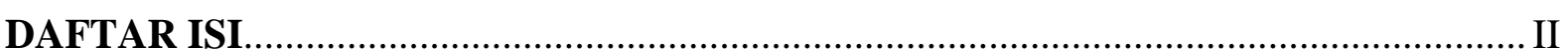

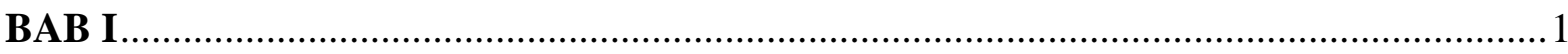

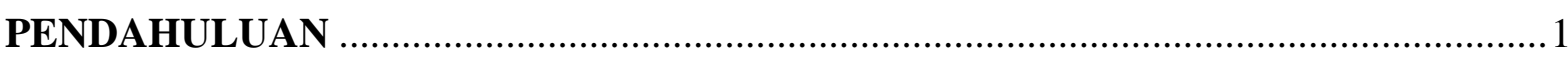

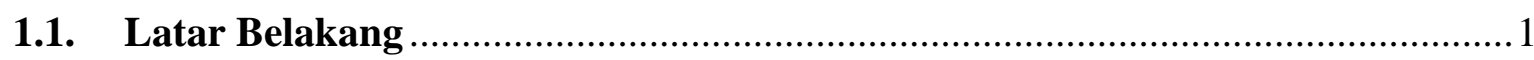

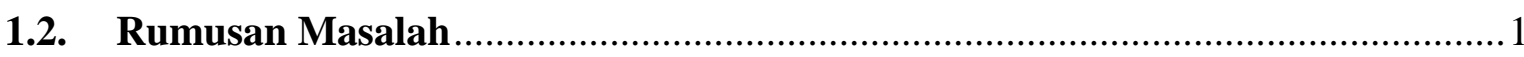

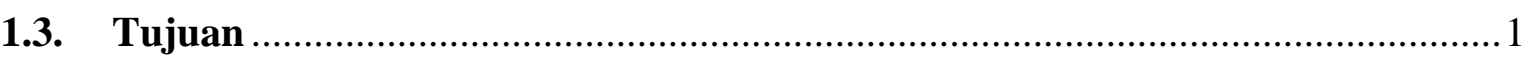

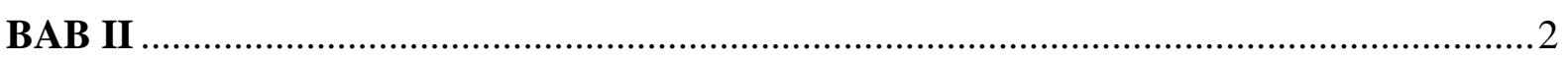

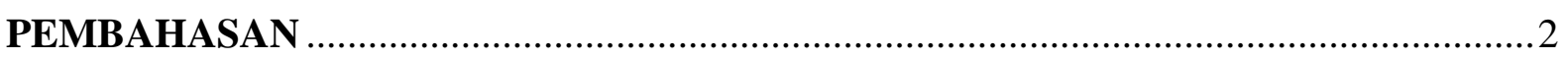

2.1. Definisi Modernisasi dan Westernisasi ......................................................... 2

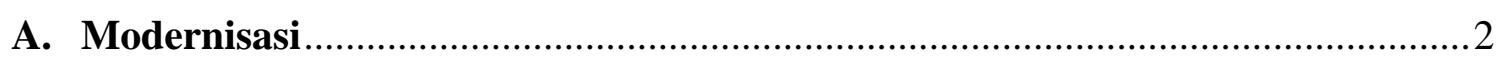

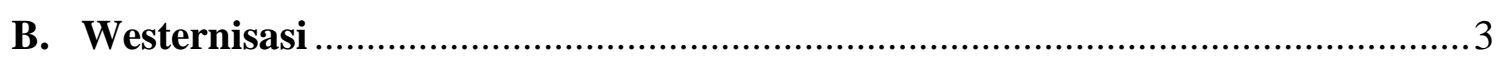

2.2. Sejarah Modernisasi dan Westernisasi ......................................................

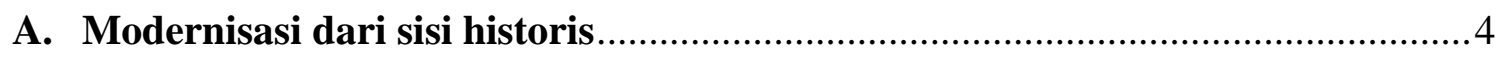

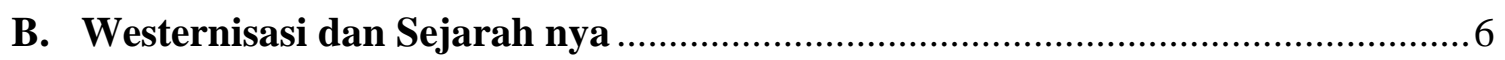

2.3. Dampak Modernisasi dan Westernisasi di Indonesia .......................................... 7

A. Dampak Modernisasi di Indonesia .............................................................. 7

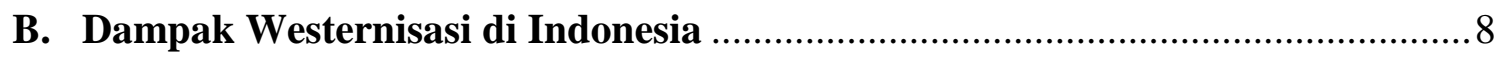

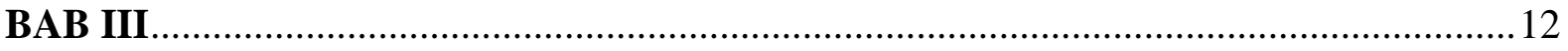

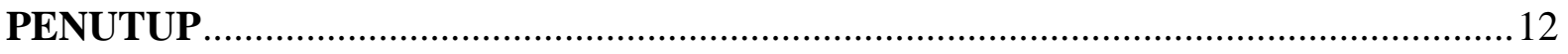

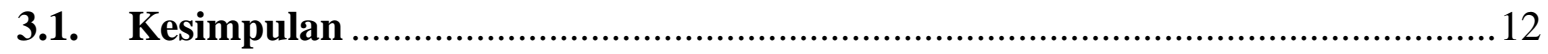

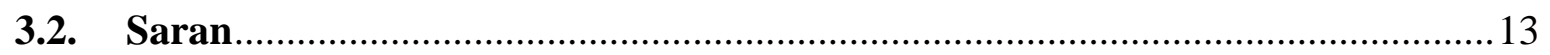

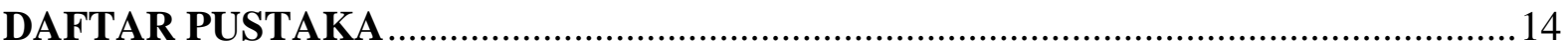




\section{BAB I \\ PENDAHULUAN}

\subsection{Latar Belakang}

Seiring dengan kemajuan teknologi dan informasi menuntut masyarakat untuk ikut terhadap perkembangan zaman tersebut. Dan harus lebih siap menghadapi perubahan dalam hal bisnis, politik, ekonomi, dan segala bidang yang mana setiap orang dituntu untuk memiliki kemampuan dan keterampilan agar bisa menjadi yang terbaik dalam persaingan di dunia internasional.

Modernisasi dan westernisasi merupakan salah satu penyebab dari perubahan zaman tersebut. Modernisasi pengaruh yang terjadi karena perkembangan teknologi dan informasi yang pesat, begitu juga dengan westernisasi merupakan sebuah pengaruh budaya barat terhadap kehidupan masyarakat Indonesia. Dengan perubahan-perubahan tersebut tentu saja dapat memberikan dampak bagi masyarakat Indonesia.

Lalu, bagaimana dampak dari dua hal tersebut kepada masyarakat Indonesia? Hal tersebut yang akan dibahas dan dikaji lebih lanjut dalam makalah ini.

\subsection{Rumusan Masalah}

1. Apa definisi modernisasi dan westernisasi?

2. Bagaimana sejarah modernisasi dan westernisasi di Indonesia?

3. Bagaimana dampak modernisasi dan westernisasi di Indonesia?

\subsection{Tujuan}

1. Mengetahui definisi dari modernisasi dan westernisasi.

2. Mengetahui bagaimana sejarah modernisasi dan westernisasi di Indonesia.

3. Mengetahui dampak modernisasi dan westernisasi di Indonesia. 


\section{BAB II}

\section{PEMBAHASAN}

\subsection{Definisi Modernisasi dan Westernisasi}

\section{A. Modernisasi}

Menurut masyarakat Barat modernisasi merupakan suatu pikiran, gerakan, aliran, dan usaha untuk mengubah paham-paham, adat-istiadat, institusi-institusi lama, dan sebagainya. Sehingga menyesuaikan suasana baru yang disebabkan oleh kemajuan ilmu pengetahuan dan teknologi modern (Nasution, 1975).

Modernisasi berarti sangat berhubungan dengan sesuatu yang baru. Menampilkan pemahaman kebaruan dari sesuatu yang dianggap tabu menjadi lebih terbuka dan moderat untuk menerima segala hal perbedaan.

Walaupun modernisasi berasal dari masyarakt barat. Akan tetapi, modernisasi ialah milik semua bangsa yang ingin mengalami kemajuan dan perubahan ke arah yang lebih baik.

Terdapat penjabaran yang sangat rinci menyangkut istilah modernisasi yang menjadi perdebatan karena multi-tafsir, yaitu sebagai berikut:

1.) Modernisasi berarti memandang ke depan, bukan ke belakang,

2.) Modernisasi memiliki sikap yang aktif dan dinamis, bukan menunggu,

3.) Modernisasi memerhatikan waktu,

4.) Modernisasi memberikan sebuah penekanan pada rasionalitas, bukan pada perasaan atau perkiraan semata,

5.) Modernisasi mengembangkan suatu sikap yang terbuka terhadap pembaharuan pemikiran,

6.) Modernisasi memberikan keutamaan pada prestasi personal, bukan hanya status yang diperoleh,

7.) Modernisasi memberikan perhatian besar terhadap masalah yang dihadapi saat ini, lebih bersifat duniawi dan konkret, dan

8.) Modernisasi lebih penting untuk mencapai tujuan dalam diri daripada tujuan kelompok. (Takdir, 2018) 
Dengan demikian, modernisasi adalah suatu perubahan dalam pikiran dan pemahaman yang baru berkaitan dengan perkembangan zaman dan perkembangan teknologi informasi, yang memiliki tujuan untuk menuju ke arah yang lebih baik atau maju.

Dapat dipahami pula bahwa modernisasi merupakan fase terkini sejarah dunia dengan ditandainya kepercayaan pada sains, perencanaan, sekularisme, dan kemajuan dalam ilmu pengetahuan (Takdir, 2018).

\section{B. Westernisasi}

Westernisasi merupakan sebuah pengaruh budaya Barat yang memberi pengaruh terhadap pola kehidupan masyarakat. hampir sama seperti pengertian modernisasi yang mana merupakan sebuah perubahan karena perkembangan zaman. Namun, westernisasi terkadang berkonotasi negatif. Dimana yang dikatakan oleh (Koentjaraningrat, 1981) bahwa proses sosial yang timbul dari suatu kebudayaan bertemu dengan unsur-unsur kebudayaan asing sedemikian rupa, sehingga dari kebudayaan itu lambat laun diterima oleh masyarakat. tanpa disadari secara perlahan akan merubah tatanan nilai dan moral yang berlaku ditempat asal masyarakat tersebut.

Secara harfiah, dalam kamus Bahasa Inggris (Wajewasoto) bahwa kata westernisasi bermakna "membaratkan" berasal dari kata westernize. Berarti menirukan gaya hidup orang Barat secara berlebihan, meniru dari segala sisi, mulai dari kehidupan, cara berpakaian, tingkah laku, budaya, dan lainnya. Di lain sisi, sikap para peniru tersebut merendahkan adat, budaya, dan bahasa nasional.

Dengan demikian, westernisasi merupakan perbuatan berlebihan terhadap Barat dengan cara mengimplementasikannya secara keseluruhan tanpa ada filter yang menyaringnya.

Dengan zaman yang semakin canggih, adanya proses interaksi antar bangsa-bangsa di dunia melalui pertukaran pelajar/mahasiswa, kunjungan wisatawan, dan sebagainya menyebabkan pengaruh budaya westernisasi yang tidak dapat terhindarkan. Sedangkan perlindungan untuk menghadapi arus pengaruh budaya tersebut sangat lemah di masyarakat, sehingga mereka meninggalkan jati dirinya sebagai bangsa yang memiliki budi luhur, tanpa mengenal batas-batas ajaran agama dan moralitas budaya. (Suharni, 2015) 


\subsection{Sejarah Modernisasi dan Westernisasi}

\section{A. Modernisasi dari sisi historis}

Seluruh masyarakat di dunia terkait dengan isu dan proses modernisasi. Modernisasi adalah transformasi masyarakat dari kehidupan tradisional (dalam artian teknologis serta organisasi sosial) ke arah pola-pola ekonomis dan politis yang menjadi ciri-ciri negara-negara Barat yang stabil yang ditandai dengan teknologi mesin, sikap rasional, sekuler, dan struktur sosial yang terdiferensias (Sztompka, 2008:149 dalam Bakri, 2016:175). Modernisasi biasa dikaitkan dengan kondisi masyarakat Barat, karena modernisasi merupakan proses perubahan menuju pada tipe sistem-sistem sosial, ekonomi, dan politik yang berkembang di Eropa Barat dan Amerika Utara abad ke-17 M sampai abad ke 19 M. Sistem sosial yang baru kemudian menyebar ke seluruh negara-negara di dunia, termasuk di negeri-negeri Muslim. Dalam teori Levy ditegaskan bahwa modernisasi ada melalui eropanisasi, pembaratan, atau amerikanisasi. Artinya, masyarakat Timur mencontoh pengalaman Barat dalam hal industrialisasi, demokrasi, dan hak asasi (Swarsono, 1991:22-26 dalam Bakri, 2016:177). Hal inilah yang menyebabkan modernisasi sering bersifat "Barat sentris".

Proses perubahan sosial dalam sebuah proses besar modernisasi melibatkan berbagai aspek dalam masyarakat, seperti politik, ekonomi, kebudayaan, dan pendidikan (Black, 1976:7 dalam Bakri, 2016:176). Karakteristik umum modernisasi antara lain adanya gerak sosial (social mobility), yaitu sebuah proses unsur-unsur sosial, ekonomi, dan psikologi yang menunjukkan peluang-peluang ke arah pola-pola baru. Adapun perwujudannya berupa mekanisasi, media yang teratur, urbanisasi, pendapatan perkapita yang naik, dan sebagainya. Dengan demikian modernisasi adalah suatu bentuk proses perubahan sosial yang terarah (directed change) yang didasarkan pada perencanaan. Modernisasi meliputi berbagai bidang yang sangat luas yang sekaligus menjadi tantangan bagi masyarakat untuk menjawabnya. Modernisasi di dunia timur dan Islam, merupakan upaya menjawab tantangan di berbagai bidang sebagai dampak dari globalisasi modernitas.

Myron Weiner (dalam Bakri, 2016:176), mendefinisikan modernisasi berdasarkan fokus ilmu yang menyertainya. Untuk itu Weiner memberi tiga bentuk studi modernisasi berdasarkan disiplin ilmu ekonomi, sosiologi, antropologi, dan ilmu politik. Ilmu ekonomi mendefinisikan modernisasi melalui pemakaian teknologi oleh manusia untuk mengolah dan mengontrol sumber ekonomi guna meningkatkan pendapatan setiap individu untuk dipasarkan. Sedangkan 
ilmu sosiologi dan antropologi memfokuskan kajian pada proses diferensiasi dalam masyarakat modern, yaitu mengkaji tentang munculnya struktur baru yang akan menyebabkan terwujudnya fungsi struktur yang baru atau menyebabkan perkembangan fungsi dari struktur yang lain. Juga akan memberi perhatian pada diferensiasi pekerjaan, seperti munculnya pekerjaan baru, pembangunan pendidikan yang semakin kompleks, dan terwujudnya komunitas baru. Sosiologi mengkaji tentang gangguan terhadap proses modernisasi, seperti muculnya tekanan, sakit mental, kejahatan, perceraian, rasial, keagamaan, konflik kelas, dan kenakalan anak-anak. Ilmu politik juga mengkaji tentang gangguan modernisasi tetapi memfokuskan pada kajian problem negara dan pembangunan pemerintahan sesuai dengan tujuan modernisasi. Kajiannya lebih memfokuskan pada kemauan pemerintah agar dapat menyesuaikan diri dengan perubahan yang dikehendaki oleh proses modernisasi, terutama dalam membuat kebijakan yang sesuai untuk masyarakat. Maka lahirlah paham Developmentalisme. Ilmu politik melihat proses modernisasi di suatu negara melalui perkembangan demokrasi, sehingga modernisasi politik identik dengan proses demokratisasi (Weiner, 1984:2-3 dalam Bakri, 2016:177).

Pola perubahan sebagai implikasi dari proses modernisasi dapat dijelaskan dalam sikap dan hubungan pekerjaan. Perubahan ini mencakupi perubahan dari pola tradisonal yang bersikap agraris berubah ke pola modern, seperti bekerja secara reguler, terikat waktu, sistem, gaji, perhatian pada skill, dan manajemen. Perubahan juga terjadi pada pola hidup dan gaya hidup, serta perubahan pada sistem keluarga dan hubungannya (Chen, 1980:240-241 dalam Bakri, 2016:177).

Memasuki abad ke-21 para pemerhati sosial sibuk dengan persoalan apakah teori-teori sosial mengalami perubahan dramatis atau tidak. Ada sekelompok ilmuwan sosial yang berpandangan bahwa masyarakat akan tetap dalam kehidupan yang bertipe modern sehingga teori sosial dapat ditata menurut mainstream teori sosial sebelumnya. Sebagian lain berpendapat bahwa masyarakat telah berubah secara dramatis dan kini masyarakat hidup dalam kondisi yang kualitasnya sangat berbeda. Maka teori sosial harus disusun dengan cara baru yang berbeda pula (Ritzer dan Goodman, 2008:104 dalam Bakri, 2016:177). Upaya penilaian ulang kajian modernisasi dan tuntutan perlunya perumusan ulang seluruh pemikrian tentang modernitas dan kemajuan telah melahirkan teori modernisasi baru (new modernization theory). 


\section{B. Westernisasi dan Sejarah nya}

Proses imperialisme dan kolonialime dalam waktu yang panjang terjadi di Indonesia memberikan dampak yang luas dalam kehidupan masyarakat. Diantara dampak itu adalah terjadinya westernisasi dalam segala segi kehidupan masyarkat Indonesia (Suharni, 2015)

Dalam lembaran sejarah Indonesia tidak pernah dijelaskan secara pasti sejak kapan proses westernisasi ini terjadi. Sebagian para pakar sejarah Islam mengatakan bahwa proses westernisasi ini terjadi sejak dimulainya kolonialisme dan imperialisme di Indonesia dan dunia Islam lainnya pada abad 19 masehi (Al-Nadwi, 1983:139 dalam Suharni, 2015:74). Hal dapat dibenarkan karena pengaruh secara langsung dapat dilakukan oleh Barat terhadap masyarakat Indonesia terjadi di era itu.

Sementara itu, pengaruh westernisasi dikalangan masyarakat muslim secara umum muncul dalam dua periode: Pertama, westernisasi muncul ketika Islam di bawah kepemimpinan Abbasyiah II. Hal tersebut disebabkan bangsa Arab mulai memasuki era kemunduran, baik di bidang politik maupun ekonomi. Pengaruh itu terlihat jelas pada era ini dengan pergeseran nilai-nilai Islam akibat takluknya wilayah-wilayah Islam. Selain itu, dapat ditandai dengan hilangnya sikap zuhud dalam tubuh masyarakat Islam. Kedua, westernisasi muncul di masa kepemimpinan Turki Usmani ketika terjadi perpecahan di antara khalifah Islam yang memberi peluang modernisasi westernisasi (Mursi, hal.50 dalam Suharni, 2015:75).

Disamping dua periode di atas, pada dasarnya proses westernisasi sudah lama terjadi melalui interaksi sarjana Barat dengan sarjana Islam di perguruan-perguruan Arab di Andalusia dan wilayah-wilayah Islam lainnya. Proses tersebut terjadi melalui penyerapan pendapatpendapat pemikir Barat atau tenaga westernisasi (Al-Saba'i, 1993:17 dalam Suharni, 2015:75). 


\subsection{Dampak Modernisasi dan Westernisasi di Indonesia}

\section{A. Dampak Modernisasi di Indonesia}

Modernisasi adalah perubahan secara total pada masyarakat yang prosesnya berlangsung cepat. Timbulnya modernisasi dapat diakibatkan oleh kemajuan ilmu dan teknologi. Secara sadar atau tidak pasti kita mengalami berbagai fenomena sosial budaya yang terjadi dalam lingkungan masyarakat kita. Fenomena ini dapat berupa perubahan gaya hidup, tata cara pergaulan, perubahan sistem kemasyarakatan, maupun hal - hal yang dapat memicu terjadinya masalah - masalah sosial yang timbul akibat perkembangan teknologi (Matondang, 2019).

Teknologi juga membuat lingkungan alam menjadi nyaman untuk didiami, aman dan efisien untuk diolah. Namun disisi lain teknologi juga menimbulkan dampak lain yang tidak diharapkan sehingga menimbulkan masalah sosial cukup pelik (Matondang, 2019)

Sebagai contoh yang mudah dipahami adalah penemuan teknologi audio visual seperti televisi. Televisi telah menimbulkan berbagai fenomena tersendiri bagi kita. Perubahan gaya hidup dalam suatu masyarakat tak dapat dihindarkan sebagai akibat pertukaran informasi budaya lewat media televisi (Matondang, 2019)

Modernisasi banyak membawa dampak bagi kehidupan semua orang, dari tingkat kanak kanak sampai tingkat orang tua. Dampak yang ditimbulkan bukan saja dampak positif, tetapi juga dampak negatif lebih - lebih bagi anggota masyarakat yang tidak banyak memperoleh nilai-nilai moral, terutama norma agama. Masalah-masalah sosial yang timbul sebgai dampak modernisasi menurut (Matondang, 2019) antara lain:

\section{a. Kesenjangan sosial ekonomi}

Kesenjangan sosial ekonomi merupakan kondisi sosial masyarakat yang sebagian berada pada tingkat kesejahteraan dan kemakmuran yang tinggi sementara sebagian berada pada tingkat yang rendah.

Tingkat kehidupan ekonomi seseorang ditentukan oleh kesempatan memenuhi kebutuhan pokok seperti sandang, pangan, dan perumahan serta kesempatan berpartisipasi dalam pembangunan. Adanya kesenjangan sosial ekonomi menunjukan perbedaan tinggi rendahnya kesejahteraan masyarakat. 


\section{b. Pencemaran lingkungan}

Pencemaran adalah berupa pengotoran yang berupa zat kimia atau limbah yang mempunyai pengaruh negatif terhadap kehidupan. Pencemaran terjadi apabila didalam lingkungan terdapat sesuatu bahan yang merugikan ekosistem dalam konsentrasi besar.

Masalah pencemaran lingkungan alam bisa dibedakan dalam beberapa klasifikasi yaitu pencemaran tanah, pencemaran air dan pencemaran udara. Pencemaran linkungan alam bisa berupa pencemaran fisik, pencemaran biologis, dan pencemaran kimiawi. Gangguan terhadap ekosistem dapat terjadi karena desakan kebutuhan manusia, bisa juga karena kurangnya kesadaran memelihara lingkungan alam. Apabila keseimbangan lingkungan alam terus terganggu, kualitas lingkungan semakin hari akan semakin menurun.

\section{c. Kriminalitas}

Bentuk kriminalitas atau tindak kejahatan ini dapat berupa pencurian, penjarahan, perampokan, perkosaan, penganiayaan, pembunuhan, korupsi, prostitusi, dan pemerasan. Proses modernisasi berberdampak pada kriminalitas atau kejahatan. Dampak ini timbul dari disorganisasi atau disintegrasi sosial seperti anomie atau kekosongan nilai dan norma. Kondisi anomie memberi peluang kearah timbulnya masalah sosial. Faktor penyebab kriminalitas antara lain krisis ekonomi, keinginan yang tidak tersalur, tekanan mental, dan dendam.

\section{d. Kenakalan remaja}

Faktor lingungan berpengaruh terhadap kenakalan remaja. Pada dasarnya yang bertanggung jawab atas masalah kenakalan remaja adalah keluarga karena fungsina setiap keluarga bertanggung jawab dalam mendidik anggota keluarnyanya agar menjadi manusia dewasa yang baik. Jelasnya modernisasi akan membawa dampak negative bagi anggota masyarakat, mulai dari kanak - kanak hingga dewasa apabila tidak dilakukan filterisasi (penyaringan) terhadap budaya - budaya asing yang masik ke Indonesia. Sehingga kehidupan sosial masyarakat dapat terpengaruhi.

\section{B. Dampak Westernisasi di Indonesia}

Perkembangan globalisasi merupakan salah satu faktor terjadi nya westernisasi, globalisasi yang menyentuh setiap lini kehidupan manusia juga berdampak terhadap perubahan budaya. 
Seperti yang diketahui, globalisasi menjadi isu yang mendapat perhatian besar sejak akhir abad ke-20 hingga abad ke-21.

Dalam proses globalisasi, batasan geografis suatu negara menjadi kabur sehingga proses globalisasi dapat mengancam eksistensi budaya suatu bangsa karena budaya lain dapat dengan mudah masuk dalam suatu kehidupan bangsa (Larasati, 2018) Dampak globalisasi,hemat Miyoshia, membuat kebudayaan nasional menjadi tidak relevan dan multikulturalisme yang berkuasa pada masa kekinian (Renton, 2009:4 dalam Anis, 2015:53).

Tidak dapat dipungkiri jika pengaruh globalisasi dalam penyebaran budaya semakin terlihat dengan adanya perkembangan teknologi informasi, sehingga penyebaran budaya tidak lagi harus melalui migrasi namun dapat dilakukan melalui media sosial dan media massa. Adanya akses internet telah memudahkan penyerapan kebudayaan karena hampir semua orang terhubung dengan jaringan internet. Media menjadi senjata utama dalam penyebaran budaya di era globalisasi, mengingat media berperan sebagai agen penyebaran budaya yang masif dengan menjadi jembatan antara agen dan konsumen. Media merupakan saluran yang berpengaruh dalam distribusi kebudayaan global yang secara langsung memengaruhi perubahan gaya hidup masyarakat dan menjadikan masyarakat sebagai konsumen suatu budaya. Jika masyarakat telah menjadi konsumen dari suatu budaya baru, maka kemungkinan akan terjadi perubahan terhadap budaya yang ada di dalam masyarakat tersebut. Hal ini diperkuat dengan hasil penelitian oleh para ahli yang mengatakan bahwa media seringkali dijadikan sebagai alat perubahan masyarakat (Li, 2004 dalam Larasati, 2018:111).

Semangat kebangsaan, jiwa kepahlawanan, rela berkorban, saling bergotong royong di kalangan masyarakat kita mulai menurun. Kita seperti telah kehilangan karakter yang selama beratus-ratus tahun bahkan berabad-abad kita bangun (Anis M. Z., 2016). Menurut hemat penulis salah satu penyebabnya adalah globalisasi yang mengirim arus westernisasi yang tidak bisa disaring oleh masyarakat sehingga masyarakat cenderung meninggalkan budaya-budaya asli bangsa.

Salah satu dampak Westernisasi yaitu budaya hedonisme. Hedonisme pada prinsipnya merupakan pandangan hidup yang menganggap bahwa tujuan hidup yang paling utama yaitu kesenangan dan kenikmatan. Budaya hedonisme ini pun didukung dengan keberadaan tempattempat produk westernisasi, seperti restoran cepat saji, pusat perbelanjaan (mall), café, club, dan sebagainya yang cenderung menjual barang ataupun jasa dengan harga yang relatif mahal. Budaya hedonisme menyebabkan masyarakat tidak keberatan untuk menghabiskan materinya 
demi mendapatkan kepuasan dan kesenangan (Larasati, 2018). Untuk lebih jelasnya menurut (Yumna, 2019) dampak westernisasi terutama untuk negara-negara timur, antara lain:

a. Westernisasi melahirkan sekularisasi. Sekularisasi adalah mengasingkan agama dari kehidupan bermasyarakat dan bernegara. Dengan ide ini masyarakat dicegah untuk melibatkan peran dan fungsi agama dalam mengatur urusan-urusan politik.

b. Westernisasi memunculkan demokratisasi dan liberalisasi. Kedua paham tersebut berasal dari dunia Barat, dengan adanya westernisasi secara tidak langsung paham tersebut mempengaruhi pola dan pikiran kita dalam dunia pemerintahan maupun perekonomian.

c. Hilangnya tradisi dan budaya asli. Dengan adanya westernisasi orang lebih banyak menghambakan kebudayaan-kebudayaan asing daripada kebudayaan sendiri

d. Dapat mengakibatkan turunnya moral penduduk suatu negara yang terkena dampak westernisasi.

e. Gaya hidup kebarat-baratan. Tidak semua budaya Barat baik dan cocok diterapkan di Indonesia. Budaya negatif yang mulai menggeser budaya asli, seperti anak tidak lagi hormat kepada orang tua.

f. Sikap individualistik. Masyarakat merasa dimudahkan dengan teknologi maju membuat mereka merasa tidak lagi membutuhkan orang lain dalam beraktifitas. Kadang mereka lupa bahwa mereka adalah makhluk sosial.

g. Pola hidup konsumtif. Perkembangan industri yang pesat membuat penyediaan barang kebutuhan masyarakat melimpah. Dengan begitu masyarakat mudah tertarik untuk mengkonsumsi barang dengan banyak pilihan yang ada.

Menurut (Yumna, 2019) dari segi manfaat, maka westernisasi bermanfaat dalam hal:

a. Perubahan tata nilai dan sikap. Adanya modernisasi dan globalisasi dalam budaya menyebabkan pergeseran nilai dan sikap masyarakat yang semula irasional menjadi rasional.

b. Berkembangnya ilmu pengetahuan dan teknologi. Dengan berkembangnya ilmu pengetahuan dan teknologi masyarakat menjadi lebih mudah dalam beraktifitas dan mendorong untuk berpikir maju.

c. Tingkat kehidupan yang lebih baik. Dibukanya industri yang memproduksi alat-alat komunikasi dan transportasi yang canggih merupakan salah satu usaha mengurangi penggangguran dan meningkatkan taraf hidup masyarakat. 
Dapat dipahami, bahwa banyak dari kita yang terkadang hanya ingin mengikuti perkembangan zaman tanpa memperhatikan dampak westernisasi itu berbahaya bagi pertahanan negara kita. Westernisasi beresiko melunturkan semangat nasionalisme para pemuda bangsa. Bukannya kita dilarang untuk menerima budaya dari luar negeri, tetapi kita diminta lebih selektif dalam menerima budaya dari bangsa lain, tanpa harus meninggalkan budaya bangsa kita sendiri (Yumna, 2019). 


\section{BAB III}

\section{PENUTUP}

\subsection{Kesimpulan}

Modernisasi merupakan sebuah pembaharuan pikiran, sikap, dan watak masyarakat yang disebabkan oleh kemajuan zaman dan perkembangan ilmu pengetahuan. Sedangkan westernisasi merupakan sebuah pengaruh budaya barat yang memberikan perubahan pada pola masyarakat, terjadi karena adanya interaksi antar bangsa-bangsa. modernisasi memiliki dampak baik terhadap perilaku masyarakat. Namun, jika masyarakat yang sulit untuk beradaptasi dengan perubahan modernisasi ini dapat berdampak buruk baginya, dan westernisasi terkadang berkonotasi negatif karena disebabkan dengan masyarakat yang meniru gaya barat tanpa disaring.

Sejarah dari modernisasi, modernisasi biasa dikaitkan dengan kondisi masyarakat Barat, karena modernisasi merupakan proses perubahan menuju pada tipe sistem-sistem sosial, ekonomi, dan politik yang berkembang di Eropa Barat dan Amerika Utara abad ke-17 M sampai abad ke 19 M. Westernisasi, dalam lembaran sejarah Indonesia tidak pernah dijelaskan secara pasti sejak kapan proses westernisasi ini terjadi. Sebagian para pakar sejarah Islam mengatakan bahwa proses westernisasi ini terjadi sejak dimulainya kolonialisme dan imperialisme di Indonesia dan dunia Islam lainnya pada abad 19 masehi menurut Al-Nadwi dalam (Suharni, 2015). Hal dapat dibenarkan karena pengaruh secara langsung dapat dilakukan oleh Barat terhadap masyarakat Indonesia terjadi di era itu. Adapun dampak dari Modernisasi di Indonesia salah satunya adalah kesenjangan sosial ekonomi merupakan kondisi sosial masyarakat yang sebagian berada pada tingkat kesejahteraan dan kemakmuran yang tinggi sementara sebagian berada pada tingkat yang rendah. Dan salah satu dampak dari Westernisasi di Indonesia adalah budaya hedonisme. Hedonisme pada prinsipnya merupakan pandangan hidup yang menganggap bahwa tujuan hidup yang paling utama yaitu kesenangan dan kenikmatan. Budaya hedonisme menyebabkan masyarakat tidak keberatan untuk menghabiskan materinya demi mendapatkan kepuasan dan kesenangan. 


\subsection{Saran}

Dalam perkembangan zaman teknologi dan informasi yang mana arus modernisasi dan westernisasi sangat deras memengaruhi sebuah kehidupan. Maka dari itu, kita harus memiliki ilmu pengetahuan yang memadai dan juga menyaring setiap perubahan yang datang. 


\section{DAFTAR PUSTAKA}

Anis, M. Z. A. (2015). Sejarah Bukan Warisan Melainkan Pembelajaran.

Anis, M. Z. A. (2016). Sejarah, Kesadaran Sejarah dan Pupusnya Identitas Nasional.

Bakri, S. (2016). Modernisasi dan Perubahan Sosial dalam Lintasan Sejarah Islam. Jurnal Studi Agama dan Pemikiran Islam, 14, 173 - 177.

Koentjaraningrat. (1981). Pengantar Ilmu Antropologi. Jakarta: PN Reneka Cipta.

Larasati, D. (2018). Pengaruh dan Eksistensi Hallyu (KoreanWave) versus Westernisasi di Indonesia. Jurnal Hubungan Internasional, 11, 109 - 116.

Matondang, A. (2019). Dampak Modernisasi Terhadap Kehidupan Sosial Masyarakat. Jurnal Wahana Inovasi, 8, 191 - 192.

Nasution, H. (1975). Pembaharuan Dalam Islam Sejarah Pemikiran dan Gerakan. Jakarta: Bulan Bintang.

Suharni. (2015). Westernisasi Sebagai Problema Pendidikan Era Modern. Jurnal AlIjtimaiyyah, 1. Retrieved 5 14, 2021, from https://www.jurnal.arraniry.ac.id/index.php/PMI/article/download/255/232

Takdir, M. (2018). Modernisasi Kurikulum Pesantren. Yogyakarta: IRCiSoD.

Wajewasoto. (n.d.). Kamus lengkap inggris Indonesia serta Indonesia Inggris, Cet.III. Jakarta: Warta, tt.

Yumna. (2019). Pendidikan Islam dalam Menghadapi Westernisasi. Jurnal Al-Karim, 4(1), $39-40$. 